\title{
Spinoza, Money, and Desire
}

\section{$\underline{\text { Abstract }}$}

In the context of Spinoza's psychological and political theory, money appears as a profound social problem. I agree with Frédéric Lordon and André Orléan that Spinoza's psychological theory can explain how multiple agents can converge on a single monetary good as a means of payment. I disagree, however, with their further claim that this convergence brings an end to rivalrous conflict among those agents. Instead, I argue, it intensifies and concentrates this rivalry, threatening the very bonds that hold society together. Yet money is, on Spinoza's account, necessary for commerce, and commerce is necessary for humans to live together. The social problem that thus arises is that of ensuring that money can play its vital role in supporting commerce without giving way to destructive rivalries that can destroy society. My interpretation of Spinoza on these points is influenced by the theory of René Girard, with which Spinoza's account has some striking parallels.

\section{Introduction}

Although Spinoza has very little to say directly about money, it is hard to believe that he did not think much about it. As Beth Lord has argued, 'money and economics are not just of marginal interest to Spinoza: they constitute a key part of his thinking about how to live with others' (Lord 2017). Frédéric Lordon and André Orléan propose that:

The instruments of thought that Spinoza provides in his Treatises, particularly in the Political Treatise, in order to account for the genesis but also the ruin of the institutions of the State, are, by a striking parallel, very susceptible of being put to work on another institutional construction: money in market societies. The political order and the monetary order are declined by one and the same grammar (Lordon and Orléan 2010, 204, my translation here and below).

Like Lordon and Orléan, I believe that to understand Spinoza's theory of money, it is crucial to understand his theory of desire, particularly its imitative and social aspects. Spinoza proposes that when we perceive others to desire something, we 
come to desire the same thing (3p27s). ${ }^{1}$ Moreover, we seek to make others desire what we desire (3p31c). Orléan, Lordon, and others have observed that Spinoza's theory entails an omnipresent threat of social unrest, grounded in the fierce affects that arise out of the dynamics of this imitative or mimetic desire. ${ }^{2}$ They have suggested that money can work to contain this threat, even transforming its psychological causes into public benefits. But, I aim to show, they have not convincingly shown that money resolves rather than intensifying the conflict.

I begin by examining the theory of money that influences Lordon and Orléan's reading of Spinoza, namely the theory that Orléan developed in collaboration with Michel Aglietta. The theory is not developed in direct reference to Spinoza, but it draws upon a hypothesis of René Girard which, as I argue below, has deep resonances with Spinoza's psychological theory. ${ }^{3}$ However, the theory diverges from Girard on one crucial point. And on this matter Spinoza and Girard are on one side, Aglietta and Orléan on the other. As a result, I argue, Lordon and Orléan's attempt to apply this monetary theory to Spinoza is not entirely successful. I then propose my own suggestions of how money fits into Spinoza's general social and political philosophy.

\section{The Aglietta-Orléan Theory of Money}

In economics textbooks we often find a theory of the origins of money that runs as follows:

Money is anything that serves as a commonly accepted medium of exchange....

As economies develop, people no longer barter one good for another. Instead, they sell goods for money and then use money to buy other goods they wish to have.... 
[T] wo monetary transactions are simpler than one barter transaction. For example, some people may want to buy apples, and some may want to sell nuts. But it would be a most unusual circumstance to find a person whose desires exactly complement your own - eager to sell nuts and buy apples. To use a classic economics phrase, instead of there being a 'double coincidence of wants,' there is likely to be a 'want of coincidence' (Samuelson and Nordhaus 2009, 458-59).

In the textbook story, agents adopt money in order to reduce transaction costs to simplify transactions. ${ }^{4}$

But Aglietta and Orléan suggest a different explanation for the origin of money. Money, on their view, arises not so much from the need to reduce transaction costs but rather from the need to conquer uncertainty:

We do not know what tomorrow will bring, not even in a probabilistic way. Now, by nature commodities [les marchandises] respond to specific needs. There are no multifunctional commodities capable of confronting an infinite diversity of future circumstances. Thus, faced with this indeterminate uncertainty, commodities are useless (Aglietta and Orléan 2002, ch.2, 'L'incertidude et la rareté', my translation here and below).

This uncertainty, which commodities on their own are powerless to confront, leads each economic agent 'to search in the goods she acquires not only for the satisfaction of her immediate needs, but above all for 'liquidity', that is to say, for the means of procuring future goods' (Aglietta and Orléan 2002, ch2., 'La question du troc'). Aglietta and Orléan refer to this also as the search for wealth: 'to search for wealth is to search for that which is desired by all - it is to search for what is universally desirable' (Aglietta and Orléan 2002, ch2., 'La question du troc'). To hold money is to have access to an indefinite variety of commodities, so long as the money is so widely desired that one can exchange it for any commodity. In this way the universal desirability of money allows it to be the antidote to uncertainty; it allows one to be prepared for the future without knowing what one will need in the future. We still must explain, however, how money can come to be universally desired. 
At this point, Aglietta and Orléan introduce a crucial hypothesis, drawn

from René Girard: the mimetic hypothesis. This hypothesis, as we shall see,

becomes crucial when Lordon and Orléan explore the Spinozistic aspects of this

monetary theory. The mimetic hypothesis, as explained by Girard, is as follows:

Once his basic needs are satisfied (indeed, sometimes even before), man is subject to intense desires, though he may not know precisely for what. The reason is that he desires being, something he himself lacks and which some other person seems to possess. The subject thus looks to that other person to inform him of what he should desire in order to acquire that being. If the model, who is apparently already endowed with superior being, desires some object, the object must surely be capable of conferring an even greater plenitude of being (Girard 2013,164).

Deep psychological complexities emerge from this situation. No sooner does the

individual imitate the desires of his model than he wishes to be imitated himself:

"he invariably falls back on the formula, "Imitate me!" in order to conceal his own lack of originality' (Girard 2013,164). Thus the mimetic nature of desire brings about a strangely symmetrical situation, in which the subject wishes both to imitate the desires of others and to have her own desires imitated. This leads to rivalry and ultimately to violence, as Aglietta and Orléan explain:

Rivalry is a consequence of imitation when, each agent taking the other for a model, the desire of the two individuals ends up converging on the same object.... The polarization of desires on the same object, subject and model becoming interchangeable, leads René Girard to call them 'mimetic doubles'. This is the situation of maximal violence. In this situation, the fact that numerous people desire the same object has no pacifying effect. Violence feeds on itself. The greater it is, the more the sacrifices are justified, since the protagonists see in it the sign that the object in question is of an extraordinary nature. This paradoxical effect is typical of the situation of the mimetic double (Aglietta and Orléan 2002, ch. 2 "L'hypothèse mimétique"). ${ }^{5}$

Aglietta and Orléan subscribe to Girard's mimetic hypothesis, but not for Girard's reasons. Whereas Girard propounds a psychological theory, Aglietta and 
Orléan arrive at his conclusions from premises that are 'not at all psychological', by which they appear to mean it arises from a specific sort of social situation rather than a psychological disposition general to all humans (Aglietta and Orléan 2002, ch.2 'L'hypothèse mimétique'). Thus they go on: 'the "lack of being" of the market individual, her fundamental incompleteness, finds its source in market alienation as a specific sort of social relation' (Aglietta and Orléan 2002, ch.2 'L'hypothèse mimétique'). It is the situation of economic uncertainty in which the individual finds herself that leads her towards a mimetic desire for wealth - that is, to an impulse to desire what others desire and to have others desire what she desires. Thus, for Aglietta and Orléan, mimetic desire is specific to the capitalist market society. A society in which ties of kinship, solidarity, etc. ensure that each agent's needs will be supplied by others, will not give rise to mimetic desire of the sort they describe. Here there is no uncertainty of the relevant kind (Aglietta and Orléan 2002, ch.2, 'L'incertitude et la rareté').

The final stage of Aglietta and Orléan's story is the resolution of the mimetic conflict through the emergence of money. At this point their thought diverges sharply from that of Girard. It is important to note this difference here, as it is relevant to a difference I shall propose between the Aglietta-Orléan theory and Spinoza's thinking. Girard envisages the end of the violent mimetic conflict through the convergence of rivalrous animosity onto a single victim - the scapegoat. Just as agents mimic each other's desires, leading to rivalrous conflict, they also mimic each other's resentments, until eventually it converges onto a single 'scapegoat victim', who is blamed for all the conflict. Aglietta and Orléan explain Girard's theory: 
The polarisation of all violent desires onto a single victim makes possible social peace and designates a culprit for all the evils that the society [cité] has experienced. His sacrifice is the occasion for a general reconciliation. Individual A ceases to resent Individual B, and vice-versa, since they both suddenly discover that their personal rivalry had for its cause the maleficent influence that the victim had unknowingly exercised. In destroying him, we eradicate the evil. René Girard speaks here of 'founding violence' (Aglietta and Orléan 2002, ch.2, 'F3 ou la violence foundatrice').

Moving to the economic case, they propose that:

In economic matters, we obtain an analogous result. The unanimity on a single object, at the same time as it expresses the greatest rivalry, since each is directly opposed to all, offers an escape to the producersexchangers: the recognition by the whole society of a common definition of wealth.... This common reference is the product of mimetic violence (Aglietta and Orléan 2002, ch.2, 'F3 ou la violence foundatrice').

But it is far from clear how this result is analogous to that of Girard. For him, the convergence of all desires on a single object is not the resolution of the mimetic conflict; it is its source. Resolution requires a shift away from the object: 'What is crucial for the resolution of [a] crisis is the shift from the desire of the object, which divides the imitators, to the hatred of the rival, which reconciles when hatred is channelled onto a single victim' (Girard 2017, 48).

Aglietta and Orléan's story does not explain who plays the role of the victim in resolving the mimetic crisis they describe. But this apparent gap is explained by the chief difference we have seen between their conception and that of Girard. For them, as we saw, the tendency towards mimetic desire, and thus towards mimetic violence, arises from the situation of economic uncertainty. The convergence upon a single monetary commodity removes the uncertainty: it allows each agent to hold money, 'liquidity', as a flexible means of procuring future goods for needs yet unknown. This removes the uncertainty the 'lack of being' that leads to mimetic desire and ultimately to rivalry - and so it resolves the mimetic conflict. But Girard could not agree with this. For him the 
source of mimetic conflict is not an economic situation of uncertainty that can be remedied by the convergence on a monetary good. It lies much deeper in human psychology.

Lying thus deeper, mimetic conflict can be resolved, according to Girard, only in two ways. The first is the scapegoating mechanism described above. But the second is by way of a public authority that exercises a monopoly on violence:

We owe our good fortune to one of our social institutions above all: our judicial system, which serves to deflect the menace of vengeance. The system does not suppress vengeance; rather, it effectively limits it to a single act of reprisal, enacted by a sovereign authority specializing in this particular function. The decisions of the judiciary are invariably presented as the final word on vengeance.... Under the public system, an act of vengeance is no longer avenged; the process is terminated, the danger of escalation averted (Girard 2013, 16-17).

I shall argue below that Spinoza similarly views public authority as the necessary means to resolve rivalrous conflict (the extent to which he considers Girard's scapegoating mechanism is a topic for another paper). Like Aglietta and Orléan, he recognises a process of psychological mimesis, by which desires can be focussed on a single monetary commodity. But unlike them, and like Girard, he does not see this convergence as a means of resolving conflicts and bringing about social unity. On the contrary, for him as for Girard, convergence on a single object is a source of conflict.

\section{Spinoza on Mimetic Desire}

To understand how far the Aglietta-Orléan theory of money applies to Spinoza, it is worth noting first that Spinoza holds a theory of mimetic desire very similar to the Girardian theory upon which Aglietta and Orléan base their analysis. Spinoza's theory of mimetic desire begins with Proposition 27 of Part 3 of the Ethics: 'If we imagine a thing like us, toward which we have had no affect, to be 
affected with some affect, we are thereby affected with a like affect.' From this arises emulation: 'the desire for a thing which is generated in us from the fact that we imagine others like us to have the same desire' (3p27s). It is worth noting that like Girard, and unlike Aglietta and Orléan, Spinoza sees this tendency as lying deep in our psychology and does not explain it by reference to specific economic circumstances.

Spinoza also believes the other side of Girard's theory: that we seek to have others desire what we desire - or more generally to share in our affective reactions to things. His explanation of this point is worth quoting in detail:

each one of us strives, so far as he can, that everyone should love what he loves, and hate what he hates. Hence that passage of the poet:

Speremus pariter, pariter mutuamus amantes;

Ferreus est, si quis, quod sinit alter, amat.

This striving to bring it about that everyone should approve his love and hate is really ambition. And so we see that each of us, by his nature, wants the others to live according to his temperament; when all alike want this, they are alike an obstacle to one another, and when all wish to be praised, or loved, by all, they hate one another (3p31c, s).

Later Spinoza points out that 'for as long as a man is bound by any desire, he must at the same time be bound by' ambition (3app44exp). Not only are we highly susceptible to emulating the desires of those around us, then; we are incapable of being bound by any desire without trying to stimulate emulation in others. It is not clear how Spinoza would deal with apparent counterexamples a baby's urge for milk does not seem to be obviously accompanied by ambition. There is no evidence that he would, as Girard does in a passage quoted above, class such an urge as a 'basic need' and thus distinguish it from a desire. Perhaps he would say that in such a case the baby is not 'bound' by desire in the relevant 
sense. For the purposes of my argument, I assume only that Spinoza believes many of the desires that drive economic activity to be accompanied by ambition.

The lines of poetry that Spinoza quotes are of great significance for explaining the role of ambition. They come from a poem in Ovid's Amores, where a lover speaks directly to his rival, enjoining him to continue acting as a rival in order to fuel his passion for his beloved. Directly before them the poem opens with the following lines:

You fool, if it does not serve you to jealously guard the girl,

Do it for my sake - it makes me want her more!

What is permitted is undesirable; what is not is more keenly desired. ${ }^{6}$ If the lovers' rivalry were simply a chance convergence of two desires on one object, the speaker in the poem could prefer for his rival to find a different girl, leaving him to pursue his beloved uncontested. But he knows that his love arises from emulation: the condition of its existence is the perceived presence of the same love in his rival. The speaker wants the rival to at least act as though he pursues the same girl, otherwise the speaker himself will find his own love weakening and vacillating.

As Girard puts it: 'Our desires are not really convincing until they are mirrored by the desires of others' (Girard 2000,14). Or, in Spinoza' terms, emulation leads to ambition: the speaker in the poem not only emulates the love of his rival, he also wishes for the rival to emulate his own love in return. Yves Citton explains Spinoza's theory in these terms:

Spinoza signals with Proposition 31 that the imitation of the affects is not only the cause of the harmonisation of desires and their inter-individual comportments. It is also, equally, the cause of the intra-mental consolidation of the affects experienced by each individual.... Put otherwise: I cannot affirm "my" desire except to the extent that it is 
affirmed in me by the confirmation received from the desires I imagine in others (Citton 2010, 127, my translation).

Ambition and emulation thus foster each other in a feedback loop. The lover desires his object because the rival desires it, and is led by ambition to encourage the rival the be an obstacle to his own desire. Thus Spinoza writes: 'each of us, by his nature, wants the others to live according to his own temperament' - that is, to desire what we desire, and thus: 'when all alike want this, they are all alike an obstacle to one another' (3p31c). The last clause is important. While there are benign cases, in which our desire to have our desire emulated leads to socially beneficial effects (Spinoza explicitly acknowledges this at 4app25), and there might well be cases that are neither benign nor malignant, the overall effect of the striving to be emulated in our desires is to make us obstacles to one another in Spinoza's view.

Is this situation inevitable? Spinoza's propositions do not appear to have universal application. One of his early critics, Christoph Wittich, complained that 3p31 describes a situation that often occurs but does not always occur: 'it is not universal and thus not demonstrable' (Wittich 1690, 194, my translation). Taking up the clue from the discussion of Ovid, however, we might suppose Spinoza's answer to point to a fundamental insecurity that all of us share to some extent. None of us is 'made of iron'; everybody will sometimes doubt that the things she desires are really worthy of her desire, and everyone will be tempted, in that situation, to try to get others to imitate her desire as a way of testing the worthiness of the objects. ${ }^{7}$ We reason, perhaps unconsciously, that it is far less likely that an object is not really worthy of desire if many desire it, and are willing to fight over it. 
Spinoza's next proposition in his excursus on desire is: 'If we imagine that someone enjoys some thing that only one can possess, we shall strive to bring it about that he does not possess it' (3p32). This is intuitive enough. But it must be noted that, on his theory, our ambition is likely to prevent us from bringing simply persuading the other not to covet the same object. Instead, we can easily find ourselves in a double-bind like that of the speaker in Ovid's poem: we want our rival to keep wanting the object that only one can possess, since this confirms its worthiness to us; and yet we want ourselves to possess the object. It is easy to see how this makes a situation of rivalry very likely to arise, and how this can lead to violence. Hobbes, who certainly influenced Spinoza, claimed in his Leviathan that:

the most frequent reason why men desire to hurt each other, ariseth hence, that many men at the same time have an appetite to the same thing; which yet very often they can neither enjoy in common, nor yet divide it; whence it follows that the strongest must have it, and who is strongest must be decided by the sword (Hobbes 1949, 1.6, 26).

But here we might pause: how many goods are there that can truly be neither enjoyed in common nor divided? Apples can be sliced. Land can be used in common. A beautiful artwork can be placed in a museum where we can all take turns enjoying it, roomful by roomful. Even romantic partners can be shared, if only the parties concerned can control their envy. But if desire is mimetic then the hope of dividing an object into equally valuable parts, whether temporal or spatial, is always precarious. There will be, in addition to the desire for the object, a desire for exclusivity, to which Hobbes refers in his definition of 'covetousness': 'Desire of Riches: COVETOUSNESSE: a name used alwayes in signification of blame; because men contending for them, are displeased with 
one anothers attaining them' (Hobbes 1968, 1.6, 123). Hobbes does not explain whence covetousness arises. But Spinoza's theory of ambition can readily fill the gap: what we want is not only to possess our object but also to have others want it. This is impossible if these others are satisfied with their own equivalent objects or portions. Ambition leads us, via covetousness, to strive to bring it about that we possess what others want, in both the archaic and modern senses of 'want'. We must take seriously the psychological sources of the Ovidian double-bind.

Ambition thus appears to be capable of undermining any simple allocation mechanism. It is not enough to divide up goods equally, or according to some principle, since what people desire is more than just the goods themselves. There is a social component to desire, captured in the notions of emulation, ambition, and covetousness. This leads to a profound political problem. The tendency to rivalry pushes humans towards a war of all against all: a struggle for exclusive possession of objects that their own psychology rather than the nature of the objects prevents them from sharing. Can the institution of money be of any use here, as the Aglietta-Orléan theory suggests? Was Spinoza in any sense aware of this possibility? We now turn to Spinoza's comments on money to explore these questions.

\section{Money as a Pacifying Instrument?}

Spinoza's brief discussion of money in the Ethics begins as follows:

the human body is composed of a great many parts of different natures, which require continuous and varied food so that the whole body may be equally capable of doing everything which can follow from its nature, and consequently, so that the mind may also be equally capable of conceiving many things. 
Now to achieve these things the powers of each man would hardly be sufficient if men did not help one another. But money has provided a convenient instrument for acquiring all these aids (4app27-8).

Spinoza does not say why the powers of each person are insufficient to provide

her with the varied sustenance life requires if people do not offer help one

another. But a similar passage in the Theological-Political Treatise goes into more

detail:

if men were not willing to give mutual assistance to one another, they would lack both skill and time to sustain and preserve themselves as far as possible. Not all men are equally capable of all things, and no one would be able to provide the things which a man alone needs most. Everyone, I say, would lack both the strength and the time, if he alone had to plow, to sow, to reap, to grind, to cook, to weave, to sew, and to do the many other things necessary to support life-not to mention now the arts and sciences which are also supremely necessary for the perfection of human nature and for its blessedness ( Spinoza 2016c, 143, III/73).

The highest level of production, of both material and spiritual goods, is achieved when each agent can produce that which she is most skilled at producing while all agents can consume the full range of goods produced.

The passage is reminiscent of a discussion in the second book of Plato's Republic. Socrates remarks that: 'more things are produced, and better and more easily when one man performs one task according to his nature, at the right moment, and at leisure from other occupations' (Plato 2013, 370c). And then a little later:

'But again, within the city itself how will they share with one another the products of their labor? This was the very purpose of our association and establishment of a state.' 'Obviously', he said, 'by buying and selling.' 'A market-place, then, and money as a token for the purpose of exchange will be the result of this' (Plato 2013, 371b).

Notice that Socrates views exchange as the link between the division of labour and money. But while Spinoza claims that 'money has provided a convenient instrument' for bringing about the aids of the division of labour is that, we have 
seen that the mimetic nature of desire can threaten the smooth operation of voluntary exchange according to his psychological theory. For exchange requires complementary desires, whereas emulation and ambition tend towards convergent desires.

This last point is explained by Aglietta and Orléan:

In effect, the place B is supposed to occupy in the exchange-relation supposes that his own goods lack use-value [for him]. But the desire of B is in every way the same as that of A. He seeks the recognition of the other. For this, he must prove that he desires the object he possesses, that is to say it comes to have use-value. But in this way the exchange-relation is reversed. .. (Aglietta and Orléan 1984, 39).

Exchange requires a situation in which A possesses s, B possesses $t$, A desires $t$, and B desires s. This is represented in the following table:

\begin{tabular}{|l|l|l|}
\hline Agent & Possesses: & Desires: \\
\hline A & $\mathrm{s}$ & $\mathrm{t}$ \\
\hline B & $\mathrm{t}$ & $\mathrm{s}$ \\
\hline
\end{tabular}

The symmetry of goods desired and goods possessed makes exchange appear possible. But suppose we start from this situation and then B emulates A's desire (perhaps encouraged by A's ambition), and B emulates A's desire. A's desire for $t$ spreads to B, and B's desire for s spreads to A. Now their desires will converge rather than coinciding:

\begin{tabular}{|l|l|l|}
\hline Agent & Possesses: & Desires: \\
\hline A & s & s and t \\
\hline B & $\mathrm{t}$ & s and t \\
\hline
\end{tabular}


Voluntary peaceful exchange is now less likely and violent rivalry more likely: both agents have intense desires for both goods - desires that strengthen as they feed upon each other. Aglietta and Orléan conclude the passage quoted above: 'we are led irrevocably towards the destructive violence of doubles, which radically excludes the double coincidence of wants by which barter could be made possible' (Aglietta and Orléan 1984, 39). Spinoza's psychological theory thus raises a problem that does not occur to Plato's Socrates. As Abba Lerner once wrote: 'An economic transaction is a solved political problem' (Lerner $1972,259)$. In order to understand how, on Spinoza's theory, money can function as a useful instrument of exchange, we must first understand how he solves the political problem of mimetic, rivalrous conflict.

It is I hope uncontroversial to claim that Spinoza's solution to most political problems is the creation of a sovereign authority. Not long after the passage quoted above, Spinoza writes: 'no society can continue in existence without authority and force, and hence, laws which moderate and restrain men's immoderate desires and unchecked impulses' ( Spinoza 2016c, 144, III/74). He also believes that people can be a help rather than a hindrance to each other to the extent that they are guided by reason, as he explains for instance in $4 \mathrm{p} 35 \mathrm{c} 2$ and 4p37s2. But there and elsewhere, he counsels caution: only very few can be led by reason all the time, and the authority of the state will always be necessary to maintain order (Spinoza 2016c, III/191).

Lordon and Orléan, however, imply that money can provide a remedy for mimetic conflict that is independent of both authority and guidance by reason. How much room is there for this theory in Spinoza? 
Lordon and Orléan suppose that money can express 'the power of the multitude', which, according to Alexandre Matheron, is capable of bringing about a sort of emergent social order through the affects of the multitude. In developing this notion of emergent social order, Lordon and Orléan draw heavily upon one passage in the Political Treatise, which reads as follows:

Men ... are guided more by affect than by reason. So a multitude naturally agrees, and wishes to be led, as if by one mind, not because reason is guiding them, but because of some common affect. As we said in iii, 9, they have a common hope, or fear, or a common desire to avenge some harm. Moreover, all men fear being alone, because no one alone has the strength to defend himself, and no one alone can provide the things necessary for life. So by nature men desire a civil order (Spinoza 2016a, 532, III/297).

Lordon and Orléan propose that:

It is this common affect that binds [soude] the group and, in doing so, engenders it and gives to it its specific power, both in the case of the political society [cité] and in that of the monetary society (Lordon and Orléan 2010, 210).

They thus develop a model of spontaneous order, in which the free play of affects gives rise to a common affect capable of binding together the society under a common authority. 'Far from the fiction of the social contract, this model proposes to think the state and money as an endogenous product of individual interests' (Lordon and Orléan 2010, 218).

It is here that Lordon and Orléan cite Matheron's story of how the social order emerges:

If one [agent] judges that the public should take the side of $\mathrm{X}_{1}$, he will do the same. And if he has guessed rightly, there will be disposed in his favour not only $\mathrm{X}_{1}$ but also a large number of other people. Now each will do the same.... $X_{1}$, in consequence, benefits from a massive help, and $X_{2}$, incapable of resisting, is legitimately crushed. All, unanimously, as if they have formed together a unique individual, punish those who defy the common opinion and protect those who follow it (Matheron 1969, 323). 
In this way, 'a collective discipline is installed'. This collective discipline can then curb the tendency to mimetic violence. On Lordon and Orléan's reading, Matheron's model is itself driven by mimesis:

This dynamic that Matheron exposes in a very detailed manner is an illustration of the laws of affective life presented in Part 3 of the Ethics. The mechanism of the imitation of the affects ... plays a central role (Lordon and Orléan 2010, 228-29). ${ }^{8}$

Thus, like Aglietta and Orléan with Girard's scapegoating model, Lordon and Orléan attempt to translate Matheron's model to explain the emergence and role of money. But in this case, as in the first, the translation is incomplete.

In the pre-monetary 'state of nature', each agent seeks "market power", which is, for Lordon and Orléan, 'the ability to make other traders recognise one's own goods as an acceptable means of payment.' They go on:

This particular form of social recognition of private products is immediately the stake for competitive conflicts, specific expressions of a marketised order of power struggles that are a type of agonistic tendencies of the conatus (Lordon and Orléan 2010, 220-21).

But then 'mimetic interactions' drive an identical dynamic to the one described by Matheron in the political domain (Lordon and Orléan 2010, 231). Increasingly all agents take the side of a single protagonist in the power struggle, until that protagonist's proper good is universally accepted as the means of payment: the monetary unit of account. ${ }^{9}$ The modern market economy, complete with a common currency, is now in place, and agents can now mutually benefit from the division of labour and trade.

Yet in a Spinozist context this story runs against a very serious problem. We have seen that, according to Spinoza, we strive that others both desire and do not possess what we desire. If a society converges on a monetary unit, everyone will desire to possess money thus defined. But will this desire not become 
covetous, as Hobbes thought the love of riches always to be? Why would a common desire for a single good not lead to rivalrous struggles for exclusive possession of that good: a situation in which 'all are alike an obstacle to one another' rather than one in which 'all, together, ... seek for themselves the common advantage of all' (4p18s)?

In fact, as we shall see in the next section, some of Spinoza's comments about money, especially when read in his historical context, suggest that it can be a source of mimetic rivalry rather than an instrument of economic order. The sources of order and unity in a monetised market economy must lie elsewhere.

\section{Money and the Political Problem}

A potential reply to the objection just raised could pick up on the specific formulation of 3p32: 'If we imagine that someone enjoys some thing that only one can possess, we shall strive to bring it about that he does not possess it' (emphasis added). We should not take too literally the highlighted phrase. Some sort of joint possession can, as we have seen, be possible in principle in nearly every case. What Spinoza is likely to have meant by 'some thing that only one can possess', however, is something such that the more of it one person uses or consumes, the less there is for others to use or consume. This is a rivalrous good, the desire for which is covetous in Hobbes's sense. Perhaps we could defend Lordon and Orléan's suggestion that the quest for money, and the convergence on the monetary unit, can lead to harmony rather than a struggle for exclusive possession, on the grounds that money is not a rivalrous good.

In an essay on property, Matheron proposes something like this. Money, being 'infinitely reproducible' need not give way to rivalrous conflict in his view 
(Matheron 2011, 254-58). The money-seeking activities of commercial competitors can yield monetary returns to all parties; this can be a positive-sum game in which 'all can simultaneously enrich themselves by working and saving'. Moreover, since what all parties desire is money in general, not any specific money-thing, they need not become obstacles to each other's pursuits:

when two individuals possess an equal sum of money they have no motive to mutual envy, since it is not the same pieces of metal but rather the same sum, and that alone, which counts in their eyes (Matheron 2011, 257-58). ${ }^{10}$

But there are many problems with this account.

In the first place, as Lord notes, 'Even if Matheron is right that Spinoza understands money to be "infinitely reproducible", this does not entail that it can be held by all equally' (Lord 2017). Lord gives some reasons why, due to the structure of the economy in Spinoza's time as well as ours, money can almost certainly not be held by all equally (Lord 2017, 2016). Moreover, the very value of the money held in surplus by some lies in the lack of it felt by others; as John Ruskin put it:

... riches are a power like that of electricity, acting only through inequalities or negations of itself. The force of the guinea you have in your pocket depends wholly on the default of a guinea in your neighbour's pocket (Ruskin 1985, 'The Veins of Wealth', 180-1)

The condition of holding more money than others - i.e., relative wealth - is a rivalrous good, and as such can easily be the source of mimetic conflict.

This effect is compounded by ambition. Continuing the passage on money quoted above, Spinoza mentions those who: 'seek money neither from need nor on account of necessities, but because they have learned the art of making money and aggrandise themselves for it very much' (4app29).11 Here he echoes

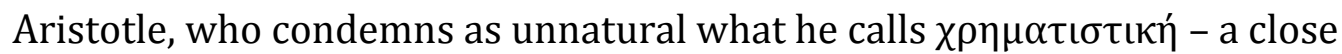


equivalent to what Spinoza calls 'artes lucri' (Aristotle 1932, 1.9). Aristotle, while

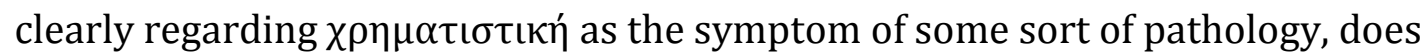
not go as far as to diagnose it. But Spinoza provides a diagnosis: the person who seeks money for its own sake does it from a desire to aggrandise herself. But someone who seeks to aggrandise herself seeks status, and status is, by its very nature, a rivalrous good: its value obviously diminishes the more it is shared. It is thus not surprising, then, that in a letter to Jarig Jelles Spinoza states that 'Republics which have an insatiable desire for honor and money must necessarily perish' (Spinoza 2016b, 2:391, IV/228). Rivalry puts people at odds with one another, and an internally conflicted republic must perish.

Matheron therefore shows more naïvety than Spinoza in proposing that the infinite reproducibility of money can exclude covetousness, ambition, envy, and the like from the pursuit of it. Matheron's mistake is to see the competitive quest for monetary wealth as a positive-sum game. If it were a quest for absolute wealth this could be. But the quest for money is generally a quest for relative wealth. This must be a zero-sum game. It easily gives way to intense feelings of ambition, and those who begin by seeking money for its power to purchase what they desire can easily turn to seeking it only to aggrandise themselves. As such, the quest for money is guaranteed to create passions that divide people rather than unifying them. As Lord describes it:

if money cannot be equally held, the society will be rife with passions. Envy increases as good fortune increases; as the rich get richer, the poor hate them all the more, and the rich fear and hate the poor in return (cf. $5 \mathrm{p} 10 \mathrm{~s}) . .$. When people are subject to these passions, they are contrary to each other and easily come into conflict (Lord 2017). 
No doubt Spinoza believed that the pursuit of money, in some sense, could promote peace and unity. Matheron refers to a passage in the Political Treatise, where Spinoza implies that a policy that forced citizens 'to engage in business dealings which are either entangled with one another or require the same means to succeed' would favour peaceful harmony, since people would then see their interests as being aligned (Matheron 2011, 258; Spinoza 2016a, 548, III/311). But engaging in commerce is not the same as pursuing money. If those pursuing money seek it only as, in Spinoza's terms, 'a convenient instrument for acquiring [the] aids' of commerce, then this can lead towards unity. Commerce, at least in the best case, is a non-rivalrous good: if the trades are positive-sum then the more I benefit from commerce the more others benefit from it also. ${ }^{12}$ Society is unified and strengthened to the extent that people desire commerce itself and strive to cause others to do the same through ambition, the positive version of which Spinoza calls 'honour' (4p37s1).

Such a positive development is, however, perpetually threatened by the process of affective mimesis that tends towards a convergence on money as an object of rivalrous desire instead of on commerce as a positive-sum activity. The multitude, Spinoza tells us, become preoccupied with the idea of money, since 'they can imagine hardly any species of joy without the accompanying idea of money as its cause' (4app28). The mere association of money with various goods - those for which money is typically exchanged - draws the mind of the multitude to desire money itself rather than the goods of commerce, through certain psychological laws of association $(3 \mathrm{p} 14, \mathrm{p} 16)$.

Spinoza was well placed to understand the way that the rivalry and distrust caused by the quest for money can ruin the benefits of commerce. First, 
there was the famous tulip crisis that occurred when Spinoza was a young child. In this crisis, Lord comments: 'The upwardly-spiralling desire for money led people to speculate on the market in the future price of bulbs' (Lord 2017). The subsequent crash and collapse of prices created a general attitude of distrust. Anne Goldgar reports how:

the damage was, for the most part, not financial. It was the confusion of values, the breakdown of honor, and the destruction of trust bound up in the events of the 1630s that caused this damage to Dutch society. These led, at the very least, to bitter disputes and anger, and even, it seems, to a questioning of truth and of reality itself (Goldgar 2008, 303).

The string of defaults and write-downs, in which creditors and debtors sought to minimise their losses by pushing them onto others, created a crisis of distrust. Creditors seemed to have a very difficult time recovering their debts. ${ }^{13}$ This in turn made ordinary commerce more difficult to pursue.

A general atmosphere of distrust drives a monetary crisis deeper. Savers attempt to maximise their money-holdings to insulate themselves from risk, minimising their spending and thus reducing the incomes of others. ${ }^{14}$ This process leads to a rivalrous process in which each agent tries to spend less than she earns. In accounting terms this is only possible if others spend more than they earn. ${ }^{15}$ Saving becomes, in a low-investment environment, another rivalrous good: a general pursuit of savings thus becomes a rivalrous power-struggle in which each person seeks to save by driving others to dis-save, while the others want it the other way around. Competitive non-spending is, of course, terrible for commerce. Worse, rivalry installs a threat of violence into the commercial environment. A striking example is found in the report that investment in the building of a new synagogue in Amsterdam was postponed in 1672, for fear of arousing envious hostility (de Vries and van der Woude 1997, 674). 
Money, in Spinoza's theory, appears as a profoundly ambivalent

institution, and monetary commerce a precarious one. The mere use of money for commercial purposes threatens, through the psychological laws of association and mimesis, to drive a rivalrous quest for relative wealth among the multitude. Far from giving rise to a spontaneous solution to a political problem, as Lordon, Orléan, and Matheron suggest, the convergence of desires onto the monetary good gives rise to a version of the political problem described by Sandra Field:

the multitude ... is ... prone to abusive and hostile relations, as antisocial passions are constantly generated by simple human experiences of scarcity, frustration, and misfortune.... To ensure that people negotiate their differences of power in healthy rather than abusive ways, creating rather than destroying social bonds, it is necessary for a society to work to create the conditions which generate the sociable passions, and limit the ramifications of the antisocial ones. In this project, the institutions of the state occupy an ambivalent role (Field 2016, 150-51).

The institution of money is similarly ambivalent. The more goods commerce brings, inevitably associated with money, the more likely the multitude is to regard money itself as the cause of the goods (rather than the help of their fellow humans). They will then develop a desire for money itself and, combining this with ambition, begin to practice the artes lucri in their most rivalrous and dangerous forms. Commerce therefore includes a natural tendency towards monetary rivalry, with which it is ultimately incompatible since one depends on social unity and the other destroys it.

\section{Conclusion}

I have examined Lordon and Orléan's attempt to apply the Aglietta-Orléan theory of money to Spinoza. The theory applies well because Spinoza shares the psychological theory of mimetic desire that underlies it. The Aglietta-Orléan 
theory that money is the result of desires converging on a single good by way of mimesis fits comfortably into the framework of Spinoza's psychological theory. But a difference emerges where the Aglietta-Orléan theory views this convergence as a positive effect, capable of ending rivalrous conflict and bringing about social order. On the contrary, while Spinoza holds that commerce can have these effects, the desire for money itself is a potential source of rivalrous conflict, as Spinoza was in a good historical position to recognise. Worse still, commerce depending on a monetary instrument can become a victim of its own success; as 'the multitude' associate the instrument with the benefits it brings, they begin to pursue it as an end in itself.

I propose that Spinoza emphasises these features of money in a way that Aglietta and Orléan (and, for that matter, Lordon and Matheron) do not because his theory of mimesis, like that of Girard, traces mimetic effects to a much deeper psychological source. For Aglietta and Orléan, as we saw, mimetic effects arise only from economic uncertainty. Uncertainty leads people to seek liquidity, as an insurance against it, which leads to a striving that others desire what they desire. But for Spinoza, as for Girard, the root of mimetic effects is a much deeper existential uncertainty: our perpetual insecurity about the true worthiness of the things we value and desire. This is not resolved by acquiring liquidity; on the contrary, liquidity itself can become the locus of further rivalry. To confirm my desire to hold liquid wealth, I need others around me to actively pursue the same. This leads readily to a rivalrous, zero-sum contest for relative wealth, which can, as Spinoza would have been well aware, turn violent in extreme cases. Money is socially useful, but it does not provide a unique solution to the problem of rivalrous desire; very easily it can become part of the problem. 
Bibliography

Aglietta, M., and Orléan, A. (1984) La violence de la monnaie. Paris, France:

Presses Universitaires de France.

Aglietta, M., and Orléan, A. (2002) La monnaie: entre violence et confiance. Paris, France: Odile Jacob. (electronic version).

Aristotle (1932) Politics. Translated by H. Rackham. Cambridge, USA: Harvard University Press.

Citton, Y. (2010) Les lois de l'imitation des affects. In Citton, Y. and Lordon, F. (eds.), Spinoza et les sciences sociales: De la puissance de la multitude à l'économie des affects (pp. 107-99) Paris, France: Éditions Amsterdam.

Douglas, A. (2016) The Affects. In Andre Santos Campos (ed.) Spinoza, (pp. 10617) Exeter, UK: Imprint Academic.

Field, S (2016) The State: Spinoza's Institutional Turn. In Andre Santos Campos (ed.) Spinoza, (pp. 142-54) Exeter, UK: Imprint Academic.

Girard, R. (2000) A Theatre of Envy. Leominster, USA: Gracewing Publishing. Girard, R. (2013) Violence and the Sacred. New York, USA: Bloomsbury Academic. Girard, R. (2017) Evolution and Conversion: Dialogues on the Origins of Culture. London, UK: Bloomsbury. Goldgar, A (2008) Tulipmania: Money, Honor, and Knowledge in the Dutch Golden Age. Chicago, USA: University of Chicago Press.

Hahn, F.H. (1989) On Some Problems of Proving the Existence of an Equilibrium in a Monetary Economy. In Starr, R. (ed.) General Equilibrium Models of Monetary 
Economies (pp. 297-306) San Diego, USA: Academic Press.

Hobbes, T. (1949) De Cive or The Citizen. Lamprecht, S (ed.). New York, USA:

Appleton-Century-Crofts.

Hobbes, T. (1968) Leviathan. Macpherson, C.B. (ed.) Harmondsworth, USA:

Pelican Books.

Lerner, A. P. (1972) The Economics and Politics of Consumer Sovereignty. The American Economic Review 62 (1/2): 258-66.

Lord, B. (2016) The Concept of Equality in Spinoza's Theological-Political Treatise. Epoché: A Journal for the History of Philosophy 20 (2), 367-86.

Lord, B. (2017) The Free Man and the Free Market: Ethics, Politics, and Economics in Spinoza's Ethics IV. In Melamed, Y.Y (ed.) The Cambridge Critical Guide to Spinoza's Ethics. Cambridge, UK: Cambridge University Press. Lordon, F (2011) L'intérêt souverain: Essai d'anthropologie économique spinoziste. Paris, France: Editions La Découverte.

Lordon, F, and Orléan, A. (2010) Genèse de l'État et genèse de la monnaie: le modèle de la potentia multitudinis. In Citton, Y. and Lordon, F. (eds.), Spinoza et les sciences sociales: De la puissance de la multitude à l'économie des affects (pp. 203-76) Paris, France: Éditions Amsterdam

Matheron, A. (1969) Individu et communauté chez Spinoza. Paris, France:

Editions de Minuit.

Matheron, A. (2011) Etudes sur Spinoza et les philosophies de l'âge classique.

Lyon, France: ENS éditions.

Orléan, A. (2014) The Empire of Value: A New Foundation for Economics.

Debevoise, M. B. (tr.) Cambridge, USA: MIT Press.

Ovid. 1989. Heroides, Amores. Showerman, G. and Goold, G.P. (tr.) Cambridge, UK: 
Loeb.

Peacock, M. (2013) Introducing Money. Milton Park, UK: Routledge.

Court, P. d. l. (1746) The True Interest and Political Maxims of the Republic of Holland. London, UK: John Campbell.

Plato (2013) Republic. Emlyn-jones, C and Preddy, W. (eds.) Cambridge, UK:

Loeb.

Robinson, J. (1969) Introduction to the Theory of Employment. London, UK:

Macmillan.

Ruskin, John. (1985) Unto This Last and Other Writings. Wilmer, C. (ed.)

Harmondsworth, USA: Penguin Classics.

Samuelson, P. A., and Nordhaus, W.D. (2009) Economics. Boston, USA: McGrawHill Education.

Spinoza, B. (1996) Ethics. Curley, E. (tr.) London, UK: Penguin Classics.

Spinoza, B. (2016a) Political Treatise. In Curley, E. (ed. and tr.) The Collected Works of Spinoza, vol.2. Princeton, USA: Princeton University Press.

Spinoza, B. (2016b) The Collected Works of Spinoza Curley, E. (ed. and tr.), vol.2.

Princeton, USA: Princeton University Press.

Spinoza, B. (2016c) Theologico-Political Treatise. In Curley, E. (ed. and tr.) The Collected Works of Spinoza, vol.2. Princeton, USA: Princeton University Press. Vega, J. d. l. (1939) Confusión de confusiones. Herdruk van den Spaanschen tekst med Nederlandsche vertaling. Smith, M. F. J (ed.) Den Haag, Netherlands: Martinus Nijhoff.

Vries, J.d., and Woude, A v.d. (1997) The First Modern Economy: Success, Failure, and Perseverance of the Dutch Economy, 1500-1815. Cambridge, UK: Cambridge University Press. 
Wittich, C. (1690) Anti-Spinoza, Sive Examen Ethices Benedicti de Spinoza, et

Commentarius de Deo et Eius Attributis. Amsterdam, Netherlands: Wolters.

1 Spinoza 1996, Part 3, Proposition 27, Scholium. All in-text references are in this format and refer to this work.

2 The term is, of course, drawn from René Girard - see below.

3 The reader may also wish to note the several references to Spinoza in Orléan 2014.

${ }^{4}$ It is not, however, clear how this could occur, since the selection of any commodity is, in game-theoretic terms, a focal point rather than an equilibrium (Hahn 1989). A helpful interdisciplinary study of this problem is found in Peacock 2013.

${ }^{5}$ See also Girard 2013, 166.

${ }^{6}$ Si tibi non opus est servata, stulte, puella,

At mihi fac serves, quo magis ipse velim!

Quod licet, ingratum est; quod non licet acrius urit.

- Amores 2.19, in Ovid 1989.

7 The account here follows that given in Douglas 2016.

8 See also: Lordon 2011.

${ }^{9}$ Lordon and Orléan note how this implies that the individuals who come to compose the state are very often (though not always) the same as those who become the monopoly producers of the means of payment, since they arise by the same process (Lordon and Orléan 2010, 259).

10 See Spinoza's letter to Jelles of 2 June 1674: Spinoza 2016b, 2:406, II/239-40b.

${ }^{11}$ I have modified Curley's translation of 'se magnifice'. Curley has 'pride themselves' but I wish to avoid confusion with 'superbia', which Curley translates elsewhere as 'pride'. See, e.g. Spinoza 1996, 84, II/159.

12 In addition, as Lord notes, 'the marketplace is an opportunity to develop more rational interactions with others' - also a common good (Lord 2017).

13 For some evidence of this see, e.g.: (Pieter de la Court 1746, 110; Vega 1939, 28) 
${ }^{14}$ De Vries and van der Woude report that: 'Dutch households must have held cash balances so large as to suggest hoarding' (de Vries and van der Woude 1997, 91).

15 An old but still accurate explanation of this point is found in (Robinson 1969, 10-13). 